\title{
Peningkatan kemampuan membaca permulaan melalui permainan kartu kata bergambar pada anak kelompok B4 di TK Negeri Pembina Bantul
}

\author{
Mediyawati \\ TK Negeri Pembina Bantul Yogyakarta \\ J1. Parangtritis Km 8.5 Tembi Timbulharjo Sewon Bantul Yogyakarta Indonesia \\ E-mail: Mediyawati71@gmail.com
}

\begin{tabular}{|c|c|}
\hline ARTICLE INFO & ABSTRACT \\
\hline \multirow[t]{2}{*}{$\begin{array}{l}\text { Article } \\
\text { history: } \\
\text { Received: } 24-04-2020 \\
\text { Revised: } 04-05-2020 \\
\text { Accepted: } 15-05-2020 \\
\text { Keywords: } \\
\text { kemampuan membaca } \\
\text { permulaan, kartu kata } \\
\text { bergambar, anak }\end{array}$} & $\begin{array}{l}\text { Kemampuan membaca permulaan perlu dikenalkan pada anak sejak dini. } \\
\text { Penelitian ini bertujuan untuk meningkatkan kemampuan membaca permulaan } \\
\text { pada anak kelompok B4 di TK Pembina Negeri Tembi Bantul. Penelitian ini } \\
\text { merupakan penelitian tindakan kelas. Adapun subjek penelitian adalah } 17 \text { anak } \\
\text { yang terdiri dari } 9 \text { anak laki-laki dan } 8 \text { anak prerempuan. Metode pengumpulan } \\
\text { data menggunakan observasi, dengan instrumen pengumpulan data berupa } \\
\text { lembar observasi. Kriteria keberhasilan dalam penelitian ini adalah apabila } 75 \% \\
\text { anak sudah mencapai BSH (Berkembang Sesuai Harapan) ataupun BSB } \\
\text { (Berkembang Sangat Baik). Adapun teknik analisis data menggunakan analisis } \\
\text { data kuantitatif dan kualitatif. Hasil penelitian menunjukkan bahwa kemampuan } \\
\text { anak dalam membaca permulaan yang berada pada kriteria BSH yang semula } 4 \\
\text { anak ( } 25 \% \text { ) pada Siklus I menjadi } 8 \text { anak (47 \%) pada Siklus II, artinya } \\
\text { mengalami peningkatan sejumlah } 22 \% \text {. Selanjutnya kemampuan anak yang } \\
\text { berada pada kriteria BSB yang semula } 4 \text { anak (25\%) pada Siklus I menjadi } 5 \\
\text { anak (30\%) pada Siklus II, artinya mengalami peningkatan sejumlah } 5 \% \text {. }\end{array}$ \\
\hline & $\begin{array}{l}\text { Beginning reading skills need to be introduced to children from an early age. } \\
\text { This study aims to improve the ability to begin reading in group B4 children in } \\
\text { TK Pembina Negeri Tembi Bantul. This research is a classroom action research. } \\
\text { The research subjects were } 17 \text { children consisting of } 9 \text { boys and } 8 \text { girls. The data } \\
\text { collection method uses observation, with data collection instruments in the form } \\
\text { of observation sheets. The criterion for success in this study is if } 75 \% \text { of children } \\
\text { have reached BSH (Developed as Expected) or BSB (Developed Very Good). The } \\
\text { data analysis technique uses quantitative and qualitative data analysis. The } \\
\text { results showed that the ability of children who were in the BSH criteria were } \\
\text { originally } 4 \text { children (25\%) in Cycle I to } 8 \text { children (47\%) in Cycle II, meaning } \\
\text { an increase of } 22 \% \text {. Furthermore, the ability of children who are in the BSB } \\
\text { criteria, which were originally } 4 \text { children (25\%) in Cycle I to } 5 \text { children (30\%) } \\
\text { in Cycle II, means an increase of 5\%. }\end{array}$ \\
\hline
\end{tabular}

\section{PENDAHULUAN}

Usia 4-6 tahun merupakan masa yang sangat penting untuk mendasari pemahaman terhadap pengetahuan, sikap, kepribadian atau lebih umum mendasari pertumbuhan dan perkembangan yang menyeluruh. Pada usia ini proses pembelajaran pada anak ditekankan pada aspek perkembangan bahasa, kognitif, fisik motorik, seni, sosial emosional, disiplin, kemandirian dan nilai-nilai agama dan moral untuk memasuki pendidikan dasar. Undang-undang Sistem Pendiddikan Nasional Nomor 20 Tahun 2003 BAB XI Pasal 40 Ayat 2 menyatakan bahwa salah satu kewajiban pendidik dan tenaga kependidikan yaitu menciptakan suasana kependidikan yang bermakna, menyenangkan, kreatif, dinamis dan dialogis. 
Pendidikan Anak Usia Dini merupakan bagian dari jenjang Pendidikan yang sangat diperlukan untuk kesiapan pada jenjang selanjutnya. Undang-undang Republik Indonesia Nomor 20 Tahun 2003 tentang Sistem Pendidikan Nasional pasal 1 ayat 14 menyatakan bahwa Pendidikan Usia Dini adalah suatu upaya pembinaan yang ditujukan kepada anak sejak lahir sampai anak usia 6 tahun yang dilakukan untuk pemberian rangsangan pendidikan untuk membantu pertumbuhan dan perkembangan jasmani dan rohani agar anak memiliki kesiapan dalam memasuki pendidikan lebih lanjut.

Ketika anak memasuki pendidikan di Taman Kanak-kanak berada pada usia 4-5 ahun. Pada masa ini merupakan masa keemasan (the golden age) perkembangan anak. Usia tersebut memiliki potensi besar untuk mengoptimalkan segala aspek perkembangannya, yakni aspek sosial-emosional dan moral, berbahasa, kognitif, seni dan aspek fisik motoriknya. Seluruh aspek perkembangan diharapkan bisa dikembangkan secara berimbang antara aspek yang satu dengan lainnya.

Anak usia taman kanak-kanak memiliki kemampuan yang akan dikembangkan diantaranya perkembangan bahasa. Perkembangan bahasa adalah proses seorang anak terampil mengolah bahasanya sehingga dapat mengkomunikasikan maksud, tujuan, pemikiran maupun perasaannya pada orang lain. Anak usia dini, khususnya usia 4-5 tahun dapat mengembangkan kosakata secara mengagumkan. Owens (dalam Papalia et al: p 1990) mengemukakan bahwa anak usia tersebut memperkaya kosakatanya melalui pengulangan. Anak usia 4-5 rata-rata dapat menggunakan 900 sampai 1000 kosakata yang berbeda dan berkembang hingga 5000-7000 kata pada usia 4-6 tahun.

Komponen perkembangan bahasa pada anak yaitu kemampuan membaca dan menyimak yang sangat berkaitan satu sama lain. Beberapa peneliti yaitu Mulholland dan Neville (dalam Bromley,1991) mengungkapkan bahwa terdapat saling ketergantungan antara membaca dan menyimak pada anak hingga usia 14 tahun. Kemampuan membaca dan menyimak melibatkan proses kognitif yang aktif yang memerlukan kemampuan berpikir kritis.

Pengembangan kemampuan membaca di Taman Kanak-kanak berkembang dalam beberapa tahap. Menurut Concrane Efal sebagaimana dikutip Brewer (1992: p 260), perkembangan dasar kemampuan membaca pada anak usia 4-6 tahun berlangsung dalam lima tahap, yakni: tahap fantasi (magical stage), pembentukan konsep diri (self concept stage), tahap membaca gambar (bridging reading stage), pengenalan bacaan (take off reader stage), dan membaca lancar (independent reader stage). Sehubungan dengan tahap-tahap perkembangan membaca pada anak, maka orang dewasa untuk menstimulasi potensi-potensi anak tersebut di atas sesuai tahap-tahap perkembanganya. Oleh karena itu, lingkungan berperan penting dalam hal ini. Lingkungan harus dapat menciptakan kegiatan-kegiatan yang dapat memekarkan potensi yang ada pada anak. Kajian tentang perkembangan membaca pada anak tidak terlepas dari kenyataan adanya perbedaan kecepatan dalam membaca maupun kualitas dan kuantitas anal dalam menghasilkan bahasa.

Kenyataan di lapangan menunjukkan bahwa belum semua anak kelompok B4 Taman Kanak-kanak Negeri Pembina Bantul memiliki kemampuan membaca. Berdasarkan pengamatan terhadap kegiatan pengembangan di kelas ditemukan adanya masalah dalam hal kemampuan membaca. Dari 17 anak, terdapat 5 anak yang kemampuan membacanya sudah lancar, dan 12 anak kemampuan membacanya belum meningkat. Sebagian besar anak sudah mengenal beberapa huruf, tetapi untuk mengenal arti kata dari gabungan beberapa huruf konsonan dan vokal belum tercapai.

Memperhatikan latar belakang objek penelitian, maka peneliti mengambil judul penelitian meningkatkan kemampuan membaca melalui permainan kartu kata bergambar. Permainan kartu kata bergambar dipilih agar anak lebih tertarik dan mudah mengingatnya. Disamping anak dapat tertarik dengan macam-macam gambarnya anak juga bisa langsung melihat kata-kata yang dicontohkan oleh guru. Dalam penggunaannya bisa divariasikan dengan kartu kalimat dan kartu huruf. Adapun kelebihan dalam kartu kata bergambar menurut Indriana (2011: p 69), yaitu: mudah dibawa ke mana-mana; praktis dalam membuat dan menggunakannya, sehingga kapan pun anak didik bisa belajar dengan baik menggunakan media ini; mudah diingat karena kartu ini bergambar yang sangat menarik perhatian; serta menyenangkan sebagai media pembelajaran, bahkan bisa digunakan dalam permainan.

Berdasarkan latar belakang masalah tersebut, maka dilakukan penelitian tindakan kelas dengan judul meningkatkan kemampuan membaca permulaan melalui kartu kata bergambar pada anak Kelompok B4 di TK Negeri Pembina Bantul. 


\section{METODE}

Jenis penelitian ini adalah Penelitian Tindakan Kelas (PTK) atau classroom action research secara kolaboratif, Kolaboratif yang dimaksud dalam penelitian ini adalah antara guru sebagai peneliti dengan teman sejawat (guru kelas lain). Adapun model yang digunakan adalah model Kemmis \& Mc Taggart yang terdiri dari empat komponen, yaitu: perencanaan, tindakan, pengamatan dan refleksi.

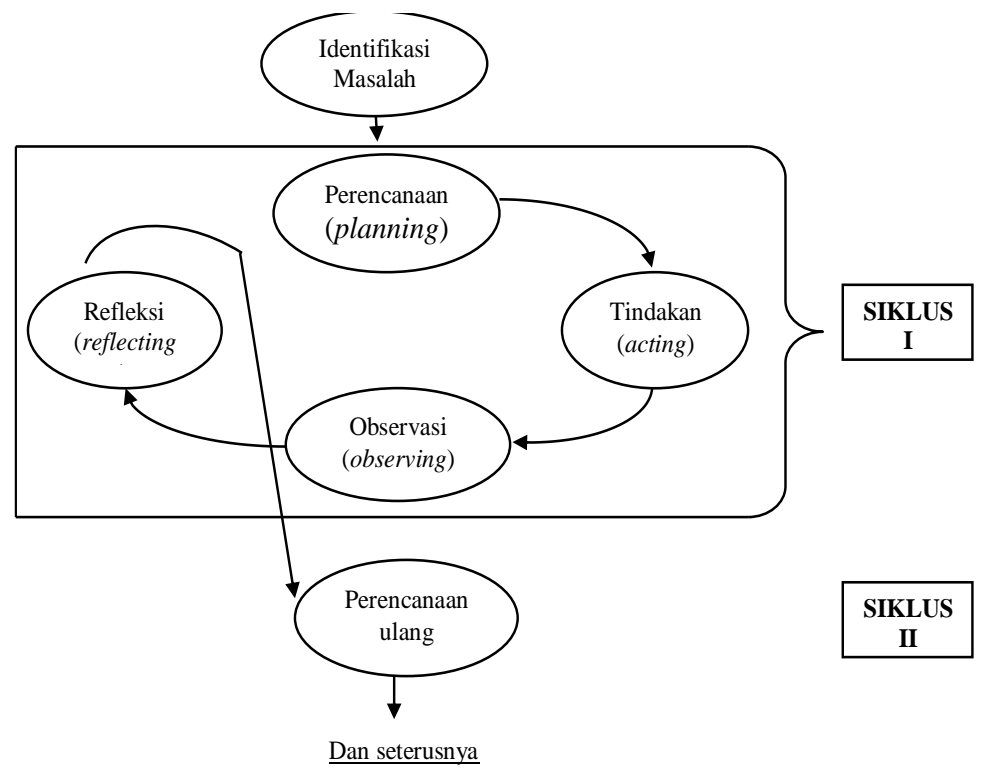

Gambar 1. Alur penelitian tindakan kelas

Teknik pengumpulan data menggunakan observasi dengan tiga aspek yang dinilai yaitu menyebutkan lambang-lambang huruf, menyebutkan kata bersuku kata awal sama, dan membaca kata berdasarkan gambar dan tulisan. Sedangkan instrument penelitian menggunakan lembar observasi dan unjuk kerja. Adapun rubrik penilaian dapat dilihat pada Tabel 2.

Tabel 1. Rubrik penilaian unjuk kerja membaca kartu kata bergambar

\begin{tabular}{|c|c|c|c|c|}
\hline \multirow{2}{*}{$\begin{array}{l}\text { Aspek } \\
\text { Penilaian }\end{array}$} & \multicolumn{4}{|c|}{ Kriteria Penilaian } \\
\hline & BSB & $\mathrm{BSH}$ & MB & BB \\
\hline $\begin{array}{l}\text { Menyebutkan } \\
\text { lambang- } \\
\text { lambang huruf. }\end{array}$ & $\begin{array}{l}\text { Anak dapat } \\
\text { menyebutkan } \\
\text { lambang- } \\
\text { lambang huruf } \\
\text { dengan cepat } \\
\text { dan tepat. }\end{array}$ & $\begin{array}{l}\text { Anak dapat } \\
\text { menyebutkan } \\
\text { lambang- } \\
\text { lambang huruf } \\
\text { tanpa bantuan } \\
\text { guru. }\end{array}$ & $\begin{array}{l}\text { Anak dapat } \\
\text { menyebutkan } \\
\text { lambang- } \\
\text { lambang huruf } \\
\text { dengan bantuan } \\
\text { guru }\end{array}$ & $\begin{array}{l}\text { Anak belum } \\
\text { dapat } \\
\text { menyebutkan } \\
\text { lambang- } \\
\text { lambang huruf. }\end{array}$ \\
\hline $\begin{array}{l}\text { Menyebutkan } \\
\text { kata bersuku } \\
\text { kata awal sama }\end{array}$ & $\begin{array}{l}\text { Anak dapat } \\
\text { menyebutkan } \\
\text { kata bersuku } \\
\text { kata awal sama } \\
\text { dengan cepat }\end{array}$ & $\begin{array}{l}\text { Anak dapat } \\
\text { menyebutkan } \\
\text { kata bersuku } \\
\text { kata awal sama } \\
\text { tanpa bantuan } \\
\text { guru }\end{array}$ & $\begin{array}{l}\text { Anak dapat } \\
\text { menyebutkan } \\
\text { kata bersuku } \\
\text { kata awal sama } \\
\text { dengan bantuan } \\
\text { guru. }\end{array}$ & $\begin{array}{l}\text { Anak belum } \\
\text { dapat } \\
\text { menyebutkan } \\
\text { kata bersuku } \\
\text { kata awal sama. }\end{array}$ \\
\hline $\begin{array}{l}\text { Membaca kata } \\
\text { berdasarkan } \\
\text { gambar dan } \\
\text { tulisan. }\end{array}$ & $\begin{array}{l}\text { Anak dapat } \\
\text { membaca kata } \\
\text { berdasarkan } \\
\text { gambar dan } \\
\text { tulisan dengan } \\
\text { cepat dan tepat }\end{array}$ & $\begin{array}{l}\text { Anak dapat } \\
\text { membaca kata } \\
\text { berdasarkan } \\
\text { gambar dan } \\
\text { tulisan dengan } \\
\text { tepat tanpa } \\
\text { bantuan guru. }\end{array}$ & $\begin{array}{l}\text { Anak dapat } \\
\text { membaca kata } \\
\text { berdasarkan } \\
\text { gambar dan } \\
\text { tulisan dengan } \\
\text { bantuan guru. }\end{array}$ & $\begin{array}{l}\text { Anak belum } \\
\text { dapat membaca } \\
\text { kata } \\
\text { berdasarkan } \\
\text { gambar dan } \\
\text { tulisan. }\end{array}$ \\
\hline
\end{tabular}


Selain itu, peneliti juga menggunakan dokumentasi berupa data-data yang terkait dengan anak seperti foto yang menggambarkan aktivitas saat mengikuti pembelajaran. Selanjutnya data yang diperoleh pada tahap pengamatan akan ditulis menggunakan teknik kuantitatif dan kualitatif deskriptif. Data observasi dan unjuk kerja akan direkap dan selanjutnya akan dianalisa secara deskriptif naratif. Adapun langkah-langkah menganalisa data sebagai berikut:

a. Data hasil observasi

Hasil penilaian dengan observasi dibandingkan dengan rubrik penilaian sehingga menghasilkan BB, MB, BSH, atau BSB.

b. Data hasil unjuk kerja

Hasil penilaian dengan unjuk kerja dibandingkan dengan rubrik penilaian sehingga akan menghasilkan $\mathrm{BB}, \mathrm{MB}, \mathrm{BSH}$, atau BSB.

Analisis data ini dapat dihitung menggunakan rumus statistik sederhana yaitu mencari persentase kemampuan anak dalam meningkatkan kemampuan membaca kartu kata bergambar. Tindakan dikatakan berhasil apabila sekurang-kurangnya 75\% anak atau 13 anak dari 17 anak di kelompok B4 dapat membaca kartu kata bergambar.

\section{HASIL DAN PEMBAHASAN}

\section{Hasil \\ Pratindakan}

Hasil pengamatan saat Pratindakan menunjukkan bahwa belum semua anak kelompok B4 Taman Kanak-kanak Negeri Pembina Bantul memiliki kemampuan membaca. Berdasarkan pengamatan terhadap kegiatan pengembangan di kelas ditemukan adanya masalah dalam hal kemampuan membaca. Dari 17 anak, terdapat 5 anak yang kemampuan membacanya sudah lancar, dan 12 anak kemampuan membacanya belum meningkat. Sebagian besar anak sudah mengenal beberapa huruf, tetapi untuk mengenal arti kata dari gabungan beberapa huruf konsonan dan vokal belum tercapai.

\section{Siklus I \\ Perencanaan Tindakan}

Perencanaan tindakan disusun meliputi perencanaan pembelajaran berupa Rencana Pelaksanaan Pembelajaran Harian (RPPH), persiapan bahan dan alat untuk kegiatan membaca kartu kata bergambar, membuat lembar penilaian observasi dan lembar unjuk kerja membaca kartu kata bergambar pada anak. Rencana pelaksanaan pembelajaran terdiri dari dua pertemuan. Pertemuan pertama membahas tema alam semesta dengan sub tema gejala alam dan sub-sub tema gunung meletus dilaksanakan pada waktu kegiatan awal menggunakan kartu nama diri anak, dan pada pertemuan ke dua dilaksanakan di area keaksaraan menggunakan kartu kata bergambar. Perencanaan selanjutnya yang dilakukan peneliti adalah menyiapkan media yaitu kartu nama diri anak, kartu kata bergambar serta instrumen penilaian.

\section{Pelaksanaan Tindakan}

Pertemuan pertama dilaksanakan pada hari Kamis tanggal 21 Februari 2019 untuk kemampuan membaca kartu kata nama diri anak. Pada kegiatan awal guru menjelaskan pada anak kegiatan mencari nama diri sendiri dengan kartu kata yang memuat nama anak. Guru mengajak anak bersama-sama tepuk nama anak, guru menunjukkan kartu kata satu per satu sampai anak tahu tiap kata pada anak sesuai namanya. Guru membagi kartu kata pada anak sesuai namanya. Anak-anak secara bergantian mengucapkan nama diri dengan keras. Guru meminta anak menyebutkan huruf-huruf pada namanya. Guru membagi kembali kartu kata secara acak. Anak menunjukkan kartu kata yang diperoleh pada temannya. Guru meminta anak mencari kartu kata yang dipegang temannya. 


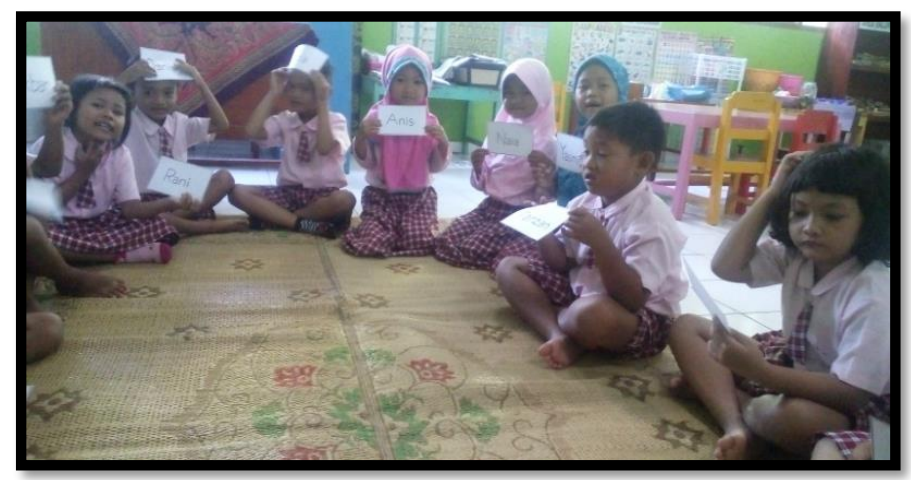

Gambar 1. Anak menunjukkan kartu kata yang memuat namanya

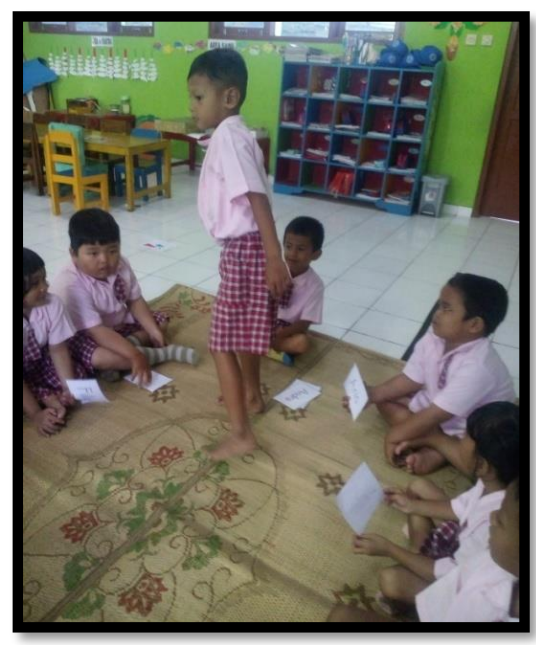

Gambar 2. Anak sedang mencari kartu nama yang dipegang teman

Pertemuan kedua dilaksanakan pada hari Senin tanggal 25 Februari 2019 untuk kemampuan mencari pasangan kartu kata dengan kartu gambar dan membacanya. Guru menyampaikan tema hari ini yaitu masih membicarakan tentang gunung meletus. Anak-anak diajak bercakap-cakap tentang banjir lahar dingin, dan guru menjelaskan kegiatan yang akan dilaksanakan di area-area, termasuk di area keaksaraan bermain dengan kartu kata bergambar. Adapun langkah-langkah bermain kartu kata bergambar antara lain:

1) Guru menunjukkan kartu kata satu persatu dengan menunggu sampai anak tahu tiap kata sebelum beralih ke kartu berikutnya.

2) Guru menunjukkan satu persatu kartu bergambar satu per satu pada anak.

3) Anak diminta menyebutkan nama gambar tersebut.

4) Guru membagi kartu kata pada anak, posisi tulisan ada di bawah.

5) Guru menata kartu bergambar bersampingan di atas meja, dan dengan aba-aba guru, anak diminta membuka kartu kata masing-masing.

6) Guru memberi waktu pada anak untuk mengenali kartu kata yang dibawa, secara bergantian anak mencari gambar sesuai dengan kartu kata yang dimilikinya.

7) Guru meminta anak menyebutkan lambang-lambang huruf.

8) Guru meminta anak mengulang membaca kartu kata tersebut.

9) Guru meminta anak menyebutkan kata yang mempunyai suku kata awal yang sama sesuai kartu kata yang dimilikinya. 


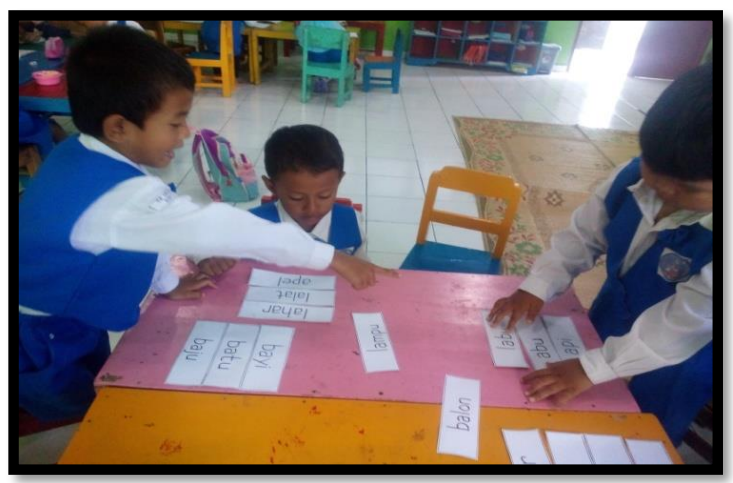

Gambar 3. Anak mengelompokkan kartu kata bersuku kata awal sama

\section{Refleksi}

Secara kualitas pelaksanaan proses pembelajaran dengan menggunakan kartu kata bergambar di kelompok B4 TK Negeri Pembina Bantul mengalami peningkatan. Hal tersebut dilihat dari kondisi atau keadaan pada pelaksanaan tindakan pada siklus I yaitu konsentrasi belajar meningkat, tanggung jawab pada tugas yang diberikan oleh guru juga baik, respon anak dalam menanggapi pertanyaan-pertanyaan guru. Namun demikian masih ada catatan dan rekomendasi agar hal tersebut dapat diperbaiki pada Siklus II, yaitu masih ada anak yang bermain pada waktu kegiatan, bercakap-cakap dengan teman sebelahnya, dan memberi tahu jawaban pada teman. Disamping itu juga ada sebagian anak yang tidak fokus dalam pembelajaran dan justru mengganggu temannya.

Tabel. 3 Penilaian kemampuan membaca kartu kata bergambar

\begin{tabular}{llll}
\hline \multirow{2}{*}{ No } & \multirow{2}{*}{ Kriteria } & \multicolumn{2}{l}{ Hasil Pengamatan } \\
\cline { 3 - 4 } & Jumlah & Persentase \\
\hline 1. & BSB dan BSH & 8 & $50 \%$ \\
\hline $2 . \quad$ MB & 8 & $50 \%$ \\
\hline Jumlah & 16 & $100 \%$ \\
\hline
\end{tabular}

Berdasarkan Tabel 3 dapat dilihat perhitungan hasil pengamatan kemampuan membaca kartu kata bergambar anak baru mencapai 8 anak (50\%) yang berada pada kriteria BSH dan BSB, serta 8 anak (50 \%) yang berada pada kriteria MB. Dari data tersebut dapat disimpulkan bahwa hasil belajar anak belum mencapai kriteria/indikator keberhasilan yang telah ditetapkan. Dengan hasil belajar pada Siklus I dianggap belum memenuhi target sebesar 75\%, sehingga penelitian dilanjutkan pada Siklus II.

\section{Siklus II}

\section{Perencanaan Tindakan}

Perencanaan tindakan disusun meliputi perencanaan pembelajaran berupa Rencana Pelaksanaan Pembelajaan Harian (RPPH), persiapan bahan dan alat untuk kegiatan menempelkan kartu kata pada gambar, membuat lembar penilaian observasi dan lembar unjuk kerja membaca kartu kata bergambar pada anak. Rencana pelaksanaan pembelajaran terdiri dari dua pertemuan. Pertemuan pertama membahas tema Negaraku dengan sub tema Kota dilaksanakan pada kegiatan inti menggunakan kartu kata bergambar, dilaksanakan di Area Keaksaraan. Perencanaan selanjutnya yang dilakukan peneliti adalah menyiapkan media yaitu kartu kata bergambar, serta instrumen penilaian. 


\section{Pelaksanaan Tindakan}

Pertemuan pertama dilaksanakan pada hari Rabu tanggal 6 Maret 2019 untuk kemampuan menempelkan kartu kata pada gambar yang sesuai. Adapun langkah-langkah bermain kartu kata bergambar antara lain, guru menunjukkan kartu kata satu persatu dengan menunggu sampai anak tahi tiap kata sebelum beralih ke kartu berikutnya. Guru menunjukkan kartu bergambar satu demi satu pada anak, anak diminta menyebutkan nama gambar tersebut, guru membagi kartu kata pada anak, posisi tulisan ada di bawah. Guru menata kartu bergambar bersampingan di atas meja, dengan aba-aba guru anak membuka kartu kata masing-masing. Guru memberi waktu pada anak untuk mengenali kartu kata yang dibawa, secara bergantian anak mencari gambar sesuai dengan kartu kata yang dimilikinya. Guru meminta anak menyebutkan lambang-lambang huruf. Guru meminta anak mengulang membaca kartu kata tersebut. Guru meminta anak menyebutkan kata yang mempunyai suku kata awal yang sama sesuai kartu kata yang dimilikinya.

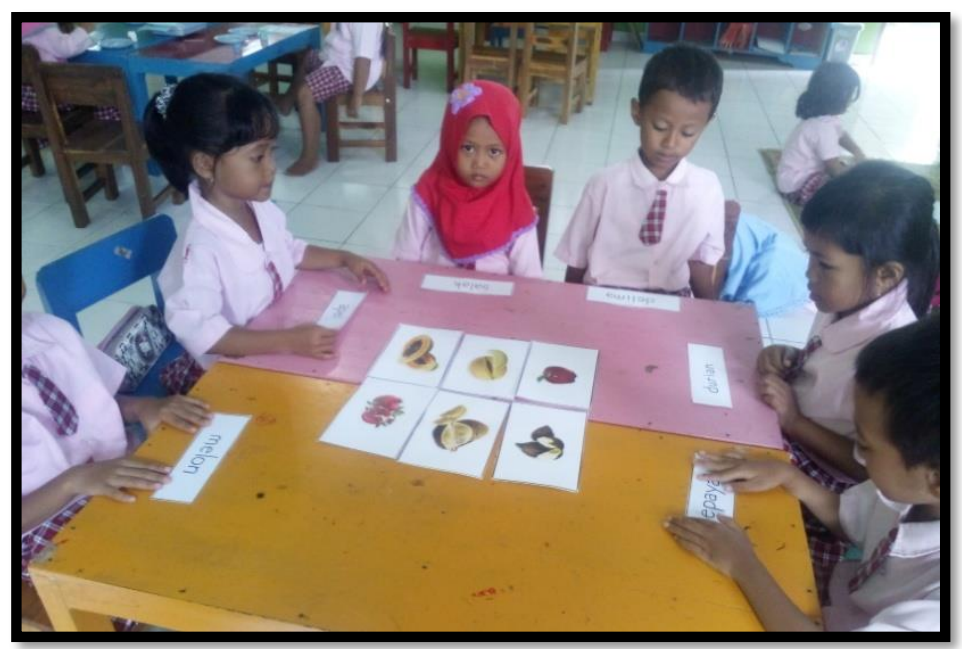

Gambar 4. Anak mengamati kartu kata yang dimiliki

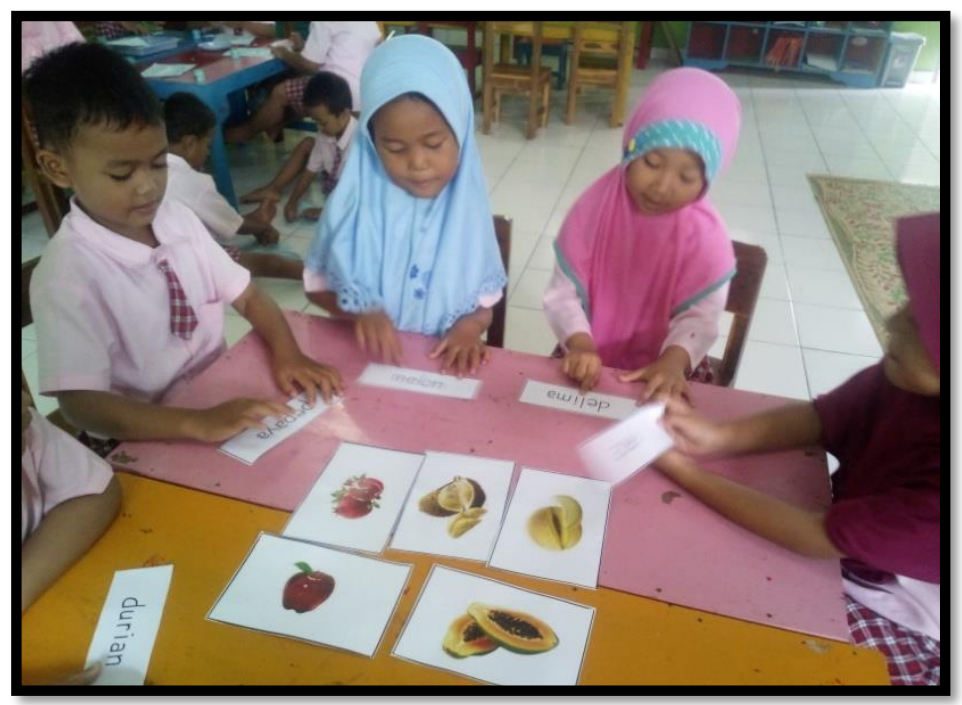

Gambar 5. Anak menyebutkan lambang-lambang huruf 
Pertemuan kedua dilaksanakan pada hari Sabtu tanggal 09 Maret 2019 untuk kemampuan membuat barisan kata. Adapun langkah-langkah bermain membuat barisan kata antara lain: guru menunjukkan kartu kata satu persatu dengan menunggu sampai anak tahu tiap kata sebelum beralih ke kartu kata berikutnya, guru menunjukkan papan karton tebal berbentuk persegi panjang, terbagi menjadi sembilan kotak, guru menumpuk kartu-kartu kata dengan sisi kata menghadap ke atas, guru minta 2 anak bergiliran mengambil sebuah kartu kata dan membaca kata pada kartu itu, kemudian melihat sebaliknya untuk mengecek apakah anak membaca dengan benar, anak meletakkan kartu bergambar pada ruang di papan karton tebal dan meletakkan sebuah keping di atasnya. Tiap pemain menggunakan keping dengan warna berlainan dan sasaran permainan adalah membuat suatu barisan tiga keping dengan warna yang sama, sepanjang garis-garis" bujur dan silang". Jika belum berhasil, kocok-kocok kartu itu dan mulai lagi.

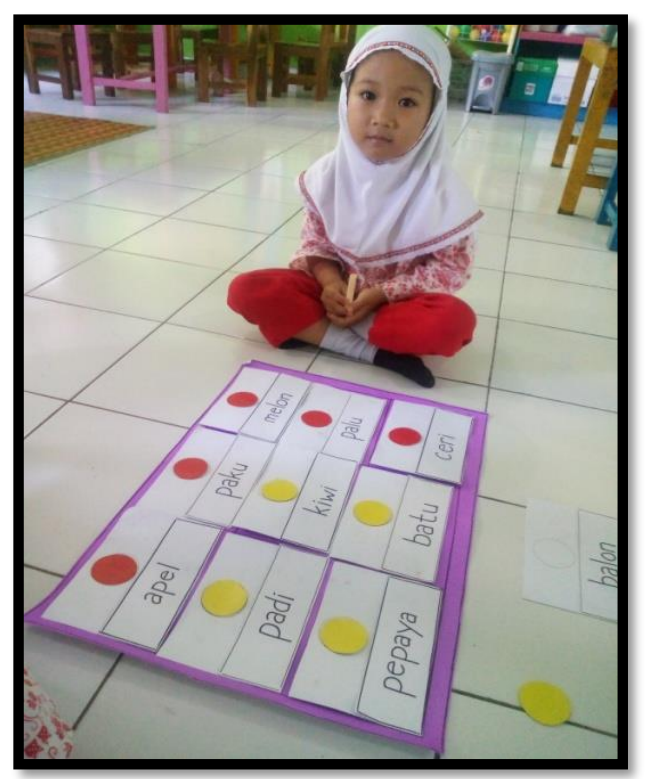

Gambar 6. Anak membuat barisan kata

\section{Refleksi}

Secara kualitas pelaksanaan proses pembelajaran dengan menggunakan kartu kata bergambar di kelompok B4 TK Negeri Pembina Bantul mengalami peningkatan. Hal tersebut dilihat dari kondisi atau keadaan pada pelaksanaan tindakan pada Siklus II yaitu konsentrasi belajar meningkat, tanggung jawab pada tugas yang diberikan oleh guru juga baik, respon anak dalam menanggapi pertanyaan-pertanyaan guru juga baik. Namun demikian masih ada catatan dan rekomendasi agar hal tersebut dapat diperbaiki pada pembelajaran selanjutnya. Diantaranya masih ada anak yang bermain pada waktu kegiatan, bercakap-cakap dengan teman sebelahnya, memberi tahu jawaban pada teman. Disamping itu juga ada sebagian anak yang tidak fokus dalam pembelajaran, ia malah mengganggu temannya.

\section{Simpulan hasil siklus II dan tindak lanjut}

Berdasarkan hasil pengamatan yang dilakukan atas sikap anak dalam pembelajaran diketahui bahwa kemampuan membaca kartu kata bergambar pada Siklus II berjalan dengan baik. Terlihat sebagian besar anak antusias mengikuti pembelajaran daripada biasanya. Dalam proses pembelajaran tampak adanya peningkatan kemampuan membaca kartu kata bergambar. Dari 17 anak, 5 anak mendapat skor berkembang sangat baik, 8 anak mendapat skor berkembang sesuai harapan, 3 anak mendapat skor mulai berkembang dan 1 anak mendapat skor belum berkembang. 
Jurnal Pendidikan Anak, Volume 9 (2), Tahun 2020

Mediyawati

Tabel 4. Penilaian kriteria kemampuan membaca kartu kata bergambar

\begin{tabular}{lccc}
\hline No & \multirow{2}{*}{$\begin{array}{l}\text { Kriteria pencapaian perkembangan } \\
\text { Anak }\end{array}$} & \begin{tabular}{c} 
Hasil Pengamatan \\
\cline { 3 - 4 } Anak
\end{tabular} & Persentase \\
\hline 1. & BSB dan BSH & 13 & $77 \%$ \\
\hline 2. & MB dan BB & 4 & $23 \%$ \\
\hline Jumlah & 17 & $100 \%$ \\
\hline
\end{tabular}

Berdasarkan Tabel 4 dapat dilihat perhitungan hasil pengamatan kemampuan membaca kartu kata bergambar anak mencapai 13 anak (77 \%) berada pada kriteria BSH dan BSB, 4 anak (23\%) berada pada kriteria MB. Dari data tersebut dapat disimpulkan bahwa hasil belajar anak telah mencapai kriteria/indikator keberhasilan yang telah ditetapkan, sehingga penelitian tindakan dihentikan.

\section{SIMPULAN}

Berdasarkan hasil penelitian di Kelompok B4 TK Negeri Pembina Bantul tahun pelajaran 2017 2018 dapat disimpulkan bahwa: kemampuan membaca permulaan dapat ditimgkatkan melalui kartu kata bergambar. Hasil penelitian menunjukkan bahwa kemampuan anak yang berada pada kriteria BSH yang semula 4 anak (25\%) pada Siklus I menjadi 8 anak $(47 \%)$ pada Siklus II, artinya mengalami peningkatan sejumlah $22 \%$. Selanjutnya kemampuan anak yang berada pada kriteria BSB yang semula 4 anak $(25 \%)$ pada Siklus I menjadi 5 anak $(30 \%)$ pada Siklus II, artinya mengalami peningkatan sejumlah $5 \%$.

\section{UCAPAN TERIMA KASIH}

Terima kasih peneliti ucapkan kepada pihak sekolah yang sangat membantu proses dari awal hingga penyelesaian penelitian ini dan tak lupa kepada teman-teman yang saling mendukung dan memberi semangat kepada peneliti.

\section{DAFTAR PUSTAKA}

Aisyah, S. dkk (2008). Perkembangan dan konsep dasar pengembangan anak usia dini. Jakarta: Universitas Terbuka.

Arikunto S., Suhardjono, S. (2012). Penelitian tindakan kelas. Jakarta: Bumi Aksara.

Depdiknas. Kurikulum 2004 Standar kompetensi taman kanak-kanak dan raudlatul athfal. Jakarta: Direktorat Jendral Manajemen Pendidikan Dasar dan Menengah.

Dhieni, N. dkk. (2007). Metode pengembangan bahasa. Jakarta: Universitas Terbuka.

Montolalu, B.E.F., dkk. (2007). Bermain dan permainan anak. Jakarta: Univrsitas Terbuka.

Nugroho, A. dkk. (2008). Kurikulum dan bahan belajar TK. Jakarta: Universitas Terbuka.

Wahyu. E. A. (2009). Efektivitas penggunan metode bermain (kartu huruf dan gambar) untuk meningkatkan prestasi belajar membaca anak berkesulitan belajar membaca anak kelas II Sekolah Dasar Negeri Kalikotes II Kabupaten Klaten Tahun Ajaran 2009-2010". Skripsi FKIP UNS Surakarta.

Wulandari, F.W. (2017). "Peningkatan kemampuan membaca permulaan melalui media kartu kata bergambar pada anak kelompok b ra guppi legundi plajan saptosari gunung kidul". Skripsi Program Studi Pendidikan Guru Pendidik Anak Usia Dini. Jurusan Pendidikan Anak Usia Dini UNY. 